\title{
Autocrine inhibition of milk secretion in the lactating tammar wallaby (Macropus eugenii)
}

\section{K A K Hendry, K J Simpson ${ }^{1}$, K R Nicholas ${ }^{1}$ and C J Wilde}

Hannah Research Institute, Ayr KA6 5HL, UK

${ }^{1}$ Victorian Institute of Animal Science, Attwood, Victoria 3049, Australia

(Requests for offprints should be addressed to C J Wilde)

\begin{abstract}
The lactating tammar wallaby progressively alters the rate of secretion and composition of its milk to provide appropriate nutrition for the developing offspring, whose needs are signalled by changes in the pattern and efficiency of its sucking. Tammars are also capable of asynchronous concurrent lactation, when the mother provides a dilute milk for a newborn young permanently attached to the teat (phase 2A of lactation), and a concentrated milk from an adjacent mammary gland for a young-atheel (phase 3). The relationship between suckling behaviour and milk secretion, and the ability of adjacent glands to function independently, suggests that milk secretion is controlled locally, within each mammary gland, by a mechanism sensitive to frequency and completeness of milk removal. To determine if tammar milk contains a factor able to control milk secretion, milk fractions have been screened in tissue and cell culture bioassays. A $6-30 \mathrm{kDa}$ fraction of phase 3 whey was found to
\end{abstract}

inhibit milk constituent synthesis and secretion in vitro, and inhibitory activity was associated with two discrete fractions obtained by anion exchange chromatography, which contained protein bands migrating anomalously at $66 \mathrm{kDa}$ and $63 \mathrm{kDa}$ in SDS-PAGE. These bands were recognised in Western blotting by antiserum raised against a bovine autocrine inhibitor of milk secretion. By the same criteria, milk secreted in phase $2 \mathrm{~B}$ of tammar lactation, when milk secretion is low and suckling intermittent but less vigorous than phase 3, also contained a feedback inhibitor of milk secretion. The results indicate that, as in dairy animals, marsupial milk secretion is under local control through feedback inhibition by a milk protein, and raise the possibility that autocrine feedback may influence the transition from phases of low milk secretion (phase 2A, 2B) to a high rate in the final third phase of lactation.

Fournal of Molecular Endocrinology (1998) 21, 169-177

\section{INTRODUCTION}

Marsupials have adopted a reproductive strategy based on a short gestation with the birth of an immature young. This is followed by extensive growth and physiological development of the dependent young during a comparatively long period of lactation (Tyndale-Biscoe \& Janssens 1988). The need to provide appropriate nutrition for this development requires that marsupials such as the tammar wallaby (Macropus eugenii) progressively alter their rate of milk secretion (Dove \& Cork 1989), and the composition and concentration of all the major milk constituents (Green 1984, Green \& Merchant 1988, Nicholas 1988a) during the course of a lactation.

Lactation in the tammar is divided into four distinct phases which correlate with changes in the secretion of specific milk proteins and changes in the sucking patterns and development of the pouch young (Nicholas et al. 1997). Phase 1 comprises mammary gland development during pregnancy and lactogenesis, which occurs at parturition. Phase 2A comprises the first 100 days of lactation when the young is in the pouch and permanently attached to the teat, and phase $2 \mathrm{~B}$ describes the subsequent 100 days when the young remains in the pouch but relinquishes the teat and sucks less frequently. Phase 2 milk is dilute, with elevated levels of carbohydrate and low levels of fat and protein (Nicholas 1988a). The transition to phase 3 of lactation is characterised by an increase in the rate of milk synthesis, and the secretion of a concentrated milk high in protein and fat and low in carbohydrate. The young grows faster in phase 3 and leaves the pouch, begins to eat herbage, but 
continues to suck the mammary gland. Induction of phase 3 lactation is accompanied by characteristic changes in milk protein gene expression. Late lactation protein (LLP)-A (LLP-A) is secreted from approximately day 160 of lactation and is maximal during phase 3 , whereas LLP-B is expressed exclusively in phase 3 (Bird et al. 1994, Nicholas et al. 1994, 1997). The $18 \mathrm{kDa}$ early lactation protein is expressed only during phase $2 \mathrm{~A}$ (Nicholas et al. 1997), whereas whey acidic protein is expressed predominantly in phase 2B (Nicholas et al. 1995, 1997). In contrast, $\alpha$-lactalbumin, $\alpha$-casein, $\beta$-lactoglobulin and $\beta-1,4$ galactosyltransferase are present throughout phase $2 \mathrm{~B}$ and phase 3 of lactation (Messer \& Elliot 1987, Bird et al. 1994, Nicholas et al. 1994).

Tammars, and other macropodid marsupials, are capable of asynchronous concurrent lactation (ACL), whereby the mother provides a dilute milk for a newborn young continually attached to the teat of one mammary gland (phase 2A) whilst supplying a concentrated milk from another mammary gland (phase 3) for a young-at-heel which has vacated the pouch (Nicholas 1988b, Nicholas et al. 1994, 1995). The ability of adjacent glands to maintain ACL demonstrates that they are functioning independently, despite being within the same systemic hormonal milieu. Independent control of milk secretion rate in each mammary gland also occurs in other mammals. In ruminants, frequency of milking regulates the rate of milk secretion by a local, i.e. intramammary mechanism (Peaker 1995), through feedback inhibition of milk secretion by a protein named FIL (feedback inhibitor of lactation; Wilde et al. 1995a). FIL is synthesised by the mammary epithelial cell and, once secreted in milk, acts on the same cells to inhibit constitutive secretion in a concentration-dependent and reversible manner (Rennison et al. 1993, Wilde et al. 1995b). Thus, the endocrine regulation of lactation is modulated by an autocrine mechanism which acts to match milk supply with demand. Local control of milk secretion by milk removal is not peculiar to ruminants; in human lactation, milk secretion rate in each breast is regulated according to completeness of breast emptying at the previous feed (Daly et al. 1993). This too may occur through feedback inhibition by a milk protein since screening of human milk constituents in mammary tissue cultures has identified a milk protein fraction which inhibits milk constituent synthesis (Prentice et al. 1989). In the tammar, induction of phase 3 lactation is accompanied by a change to less frequent but more vigorous (and presumably more efficient) sucking by the young. Therefore, one possible explanation for the difference between adjacent mammary glands in the tammar is that gland development and the increase in milk secretion is led by the offspring through changes in the pattern and completeness of milk removal. To investigate this possibility, we have screened tammar milk in mammary tissue and cell cultures, to determine if it contains a factor able to exert feedback inhibition on milk secretion.

\section{MATERIALS AND METHODS}

\section{Materials}

Culture media were obtained from Northumbria Biologicals (Cramlington, UK) or Life Technologies (Uxbridge, UK). Collagenase (Worthington type III, $150 \mathrm{U} / \mathrm{mg}$ ) was from Lorne Laboratories (Reading, Berks, UK). Hormones, antibiotics, calf thymus DNA and general laboratory chemicals were from Sigma Chemical Company, Poole, Dorset, UK. $\left[\mathrm{U}-{ }^{14} \mathrm{C}\right]$ glucose was from Amersham International, Little Chalfont, Bucks, UK. L- $\left[4,5-{ }^{3} \mathrm{H}\right]$ leucine was from ICN Biomedicals Ltd, High Wycombe, UK. Ultrafiltration membranes were from Amicon Ltd, Stonehouse, UK.

\section{Animals}

Tammar wallabies were bred and kept in open grassed yards at the Victorian Institute of Animal Science, Attwood, Victoria, Australia. The animals had free access to water and supplements of lucerne, hay and oats. The stage of lactation was determined from known birth dates or by measurement of the head length of pouch young (Poole et al. 1991). Mid-pregnant New Zealand White and nonpregnant female Dutch rabbits were from Hi-Line, Lymm, Cheshire, UK. Mice were Tuck's no. 1 strain (H Tuck \& Son, Battlebridge, UK).

\section{Milk sampling and fractionation}

Milk samples were collected from 13 tammars milked at 2-3 weekly intervals over a 6 month period encompassing phase 3 of lactation. In addition, 20 animals were sampled on one occasion only during phase $2 \mathrm{~B}$ of lactation (day $150-170$ of lactation). The animals were caught in the field, separated from their young for $4 \mathrm{~h}$ and milked under short-term general anaesthesia (methohexitone sodium (Breital); Eli Lilly, West Ryde, Australia) after intramuscular injection of $0 \cdot 1 \mathrm{U}$ of oxytocin (Heriot Agvet Pty Ltd, Rowville, Australia). Milk samples were immediately frozen at $-20{ }^{\circ} \mathrm{C}$ and shipped to the UK on dry ice. The average volume of milk collected in phase $2 \mathrm{~B}$ was $0.5 \mathrm{ml}$. 
Milk samples were thawed at ambient temperature $\left(18-20^{\circ} \mathrm{C}\right)$, pooled as necessary, and phenylmethane sulphonyl fluoride (PMSF; $2 \mathrm{mM}$ final concentration) and $\varepsilon$-amino-n-caproic acid $(15 \mathrm{mM}$ final concentration) were added to inhibit protease activity. The milk was defatted by centrifugation $\left(800 \mathrm{~g}, 20^{\circ} \mathrm{C}, 20 \mathrm{~min}\right)$ and filtration through glass wool, and the infranatant was centrifuged at $80000 \mathrm{~g}$ for $2 \mathrm{~h}$ at $20^{\circ} \mathrm{C}$ to produce a casein pellet and a whey supernatant. The whey was ultrafiltered using a $30 \mathrm{kDa}$ cut-off membrane (Amicon YM30) and dialysed extensively against water (Spectropor-1; Pierce and Warriner, Chester, UK) to obtain a $6-30 \mathrm{kDa}$ fraction. Both the dialysate $(6-30 \mathrm{kDa})$ and retentate (products $>30 \mathrm{kDa})$ were lyophilised and stored at $-20{ }^{\circ} \mathrm{C}$.

The $6-30 \mathrm{kDa}$ fraction was reconstituted in $10 \mathrm{mM}$ imidazole buffer $\mathrm{pH} 7 \cdot 0$, filtered through a $0 \cdot 2 \mu \mathrm{m}$ filter and applied to a HR 5/5 Mono-Q column (Pharmacia, Milton Keynes, Bucks, UK). Bound proteins were eluted with a $0-1 \cdot 0 \mathrm{M} \mathrm{NaCl}$ gradient in the same buffer. Fractions were collected by increments of the salt gradient or on the basis of $\mathrm{A}_{280}$ elution profile, dialysed for $24 \mathrm{~h}$ against water at $4{ }^{\circ} \mathrm{C}$ with several changes, freezedried, and stored at $-20{ }^{\circ} \mathrm{C}$ for testing in mammary explant or acini bioassays.

Anion exchange fractions were reconstituted in $50 \mathrm{mM}$ Tris- $\mathrm{HCl} \mathrm{pH} 7 \cdot 5$ containing $100 \mathrm{mM} \mathrm{KCl}$ and subjected to gel filtration on a Superose 12HR 10/30 column (Pharmacia Biotech, St Albans, UK). The column was calibrated by using molecular mass standards in the range $200 \mathrm{Da}$ to $6.5 \mathrm{kDa}$, and the molecular mass of eluted material was calculated from plots of $\log$ molecular masses of standards versus $\mathrm{V}_{\mathrm{e}} / \mathrm{V}_{\mathrm{o}}$, where $\mathrm{V}_{\mathrm{o}}$ is the void volume and $\mathrm{V}_{\mathrm{e}}$ the elution volume of the protein.

\section{Bioassay of milk fractions}

Ultrafiltered whey and anion exchange fractions thereof were tested for their ability to inhibit casein and lactose synthesis in mammary tissue explants prepared from mid-pregnant rabbits. Groups of 30 explants were cultured in Medium 199 containing bovine insulin $(5 \mu \mathrm{g} / \mathrm{ml})$, hydrocortisone $(0 \cdot 1 \mu \mathrm{g} / \mathrm{ml})$ and ovine prolactin $(1 \mu \mathrm{g} / \mathrm{ml})$ for $48 \mathrm{~h}$, with milk fractions added at $33 \mu \mathrm{g} / \mathrm{ml}$ for the final $6 \mathrm{~h}$ of culture. Fractions were tested in triplicate in each experiment. Average rates of casein and lactose synthesis over the $6 \mathrm{~h}$ period were measured by incorporation of $\mathrm{L}-\left[4,5-{ }^{3} \mathrm{H}\right]$ leucine $(2 \cdot 22 \mathrm{mCi} /$ $\mathrm{mmol})$ and $\left[\mathrm{U}_{-}{ }^{14} \mathrm{C}\right]$ glucose $(0 \cdot 18 \mathrm{mCi} / \mathrm{mmol})$ respectively. At the end of culture, the explants were removed, blotted, weighed and stored in liquid $\mathrm{N}_{2}$. Explants were homogenised in $10 \mathrm{mM}$ Tris- $\mathrm{HCl}$
pH $7 \cdot 0$ containing $5 \mathrm{mM}$ EGTA and $2 \mathrm{mM}$ PMSF by ten strokes with a glass-Teflon homogeniser, followed by sonication (Kontes KT50 cell disrupter, setting $30,30 \mathrm{~s}) .\left[{ }^{3} \mathrm{H}\right]$ Casein was isolated from the homogenate by preparation of a particlefree supernatant $\left(10000 \mathrm{~g}, 5 \mathrm{~min}, 4^{\circ} \mathrm{C}\right)$, isoelectric precipitation, and SDS-PAGE (Wilde et al. 1984). $\left[{ }^{14} \mathrm{C}\right]$ Lactose was measured by selective precipitation from culture medium and explant homogenates (Kuhn \& White 1975). Casein and lactose synthesis were expressed relative to explant DNA content measured by a fluorimetric method (Labarca \& Paigen 1980).

Milk fractions available only in small quantities were screened for inhibition of secretion in mouse mammary acini, a system which has served to characterise the autocrine inhibitor in goat's milk (Rennison et al. 1993). Mammary acini were prepared from tissue of lactating mice on day 8-10 of lactation. Tissue was finely chopped and digested with collagenase (type $3 ; 1.2 \mathrm{mg} / \mathrm{ml}$ ) for $90 \mathrm{~min}$ at $37^{\circ} \mathrm{C}$ in Hanks' balanced salt solution $\mathrm{pH} 7 \cdot 4$ (HBSS) containing $10 \mathrm{mM}$ Hepes, insulin $(5 \mu \mathrm{g} / \mathrm{ml})$ and hydrocortisone $(10 \mathrm{ng} / \mathrm{ml})$. When the digest consisted predominantly of groups of 50-200 cells, the cell suspension was filtered through monofilament nylon mesh $(53 \mu \mathrm{m}$ pore size) and cells were harvested by centrifugation $(80 \boldsymbol{g}, 5 \mathrm{~min})$. The cell pellet was washed four times in HBSS containing insulin, hydrocortisone, DNase I $(0.04 \mathrm{mg} / \mathrm{ml}$; Boehringer, Lewes, E. Sussex, UK) and trypsin inhibitor $(0 \cdot 1 \mathrm{mg} / \mathrm{ml})$, then resuspended in culture medium (Medium 199/Ham's F12; 50:50 $\mathrm{v} / \mathrm{v})$ containing insulin $(5 \mu \mathrm{g} / \mathrm{ml})$, hydrocortisone $(0 \cdot 1 \mu \mathrm{g} / \mathrm{ml})$ and prolactin $(1 \mu \mathrm{g} / \mathrm{ml})$ at $1.5 \times 10^{6}$ cells $/ \mathrm{ml}$ and cultured at $37^{\circ} \mathrm{C}$ in an atmosphere of $5 \cdot 0 \% \mathrm{CO}_{2}$ in air. Cell number was determined by packed cell volume under standard centrifugation conditions, using pre-determined standard values. Protein synthesis and secretion were measured by continuous labelling with $\mathrm{L}-\left[4,5-{ }^{3} \mathrm{H}\right]$ leucine $(10 \mu \mathrm{Ci} /$ $\mathrm{ml}$ ) for $2 \mathrm{~h}$ in the presence or absence of anion exchange fractions $(5-30 \mu \mathrm{g}$ protein $/ \mathrm{ml}$; three replicates per experiment). The culture was terminated by centrifugation of the cell suspension $(500 \mathrm{~g}$, $1 \mathrm{~min})$, and the cell pellet and supernatant were frozen and stored at $-20{ }^{\circ} \mathrm{C}$. Radiolabel incorporated in cellular and secreted protein was assayed by precipitation with trichloroacetic acid (final concentration $10 \%$, w/v). Cell lysates were prepared by sonication (Kontes KT50 cell disrupter, Uxbridge, UK; setting 20, 15 s) in $0 \cdot 1 \mathrm{M} \mathrm{NaH}_{2} \mathrm{PO}_{4}$ pH $7 \cdot 4$ containing $2 \mathrm{M} \mathrm{NaCl}$ and assayed for DNA content (Labarca \& Paigen 1980). Synthetic and secretory activity were expressed per unit DNA. 


\section{Protein analysis}

The composition of tammar whey fractions was analysed by SDS-PAGE in 10\% gels under reducing conditions (Laemmli 1970). Gels were stained with Coomassie Blue or blotted onto PVDF membrane (Millipore) using standard methods ('Towbin et al. 1979). Membranes were blocked for a minimum of $1 \mathrm{~h}$ at $4{ }^{\circ} \mathrm{C}$ with $4 \%(\mathrm{w} / \mathrm{v})$ gelatin in PBS containing $0 \cdot 1 \%(\mathrm{v} / \mathrm{v})$ Tween 20 (PBST) and incubated for $2 \mathrm{~h}$ at room temperature with polyclonal rabbit antisera to tammar $\alpha$-lactalbumin (1:500, Maher \& Nicholas 1987), tammar LLP-A (1 $\mu \mathrm{g} \mathrm{IgG} / \mathrm{ml}$; Nicholas et al. 1994), ovine $\beta$ lactoglobulin (1:500; Osborne et al. 1995) or bovine FIL (1:500; Wilde et al. 1995a). Blots were washed three times in PBST, and developed by sequential incubation with goat anti-(rabbit Ig)-alkaline phosphatase conjugate and bromochloroindolyl phosphate/nitro blue tetrazolium substrate (Sigma) according to the manufacturer's instructions. When only a small amount of protein was available, as with phase $2 \mathrm{~B}$ milk, fractions were resolved in high density Phastgels and silver stained using the Phast silverstain kit (Pharmacia).

\section{ELISA}

Whey fractions obtained by anion exchange chromatography were diluted to $1 \mu \mathrm{g} / \mathrm{ml}$ in coating buffer $\left(15 \mathrm{mM} \mathrm{Na} \mathrm{CO}_{3}, 35 \mathrm{mM} \mathrm{NaHCO}, 3 \mathrm{mM}\right.$ $\mathrm{NaN}_{3}, \mathrm{pH} 9 \cdot 6$ ), and used to coat microtitre plates (Dynatech, Billingshurst, UK) by incubation at $4{ }^{\circ} \mathrm{C}$ for $16 \mathrm{~h}$. The wells were blocked with $0.5 \%(\mathrm{w} / \mathrm{v})$ gelatin in the same buffer, washed with PBST then incubated at room temperature for $2 \mathrm{~h}$ with $100 \mu \mathrm{l}$ PBST containing polyclonal antisera against tammar $\alpha$-lactalbumin (1:500 dilution), tammar LLP-A $(1 \mu \mathrm{g} \quad \mathrm{IgG} / \mathrm{ml})$ or ovine $\beta$-lactoglobulin (1:500 dilution). After repeated washing, binding was determined by incubation with anti-(rabbit Ig)-horseradish peroxidase conjugate (Scottish

TABLE 1. Inhibition of lactose synthesis in rabbit tissue explants by whey fractions of tammar milk. Whey prepared from phase $2 \mathrm{~B}$ and phase 3 milk was ultrafiltered using membranes with a nominal molecular mass cut-off of $30 \mathrm{kDa}$. Inhibition of lactose synthesis in rabbit tissue explants is expressed as a percentage compared with untreated controls. Values are means \pm S.E.M. for three determinations $* n=2$

\begin{tabular}{lrcc} 
& Phase 2B & & Phase 3 \\
\cline { 2 - 2 } Whey fraction & $28 \cdot 7 \pm 0 \cdot 9$ & & $0 \cdot 9 \pm 0 \cdot 1$ \\
Total & $38 \cdot 2 \pm 5 \cdot 9$ & & $35 \cdot 1 *$ \\
$6-30 \mathrm{kDa}$ & $0 \cdot 4 \pm 0 \cdot 1$ & & $0 \cdot 1 \pm 0 \cdot 1$ \\
$>30 \mathrm{kDa}$ & & \\
\hline
\end{tabular}

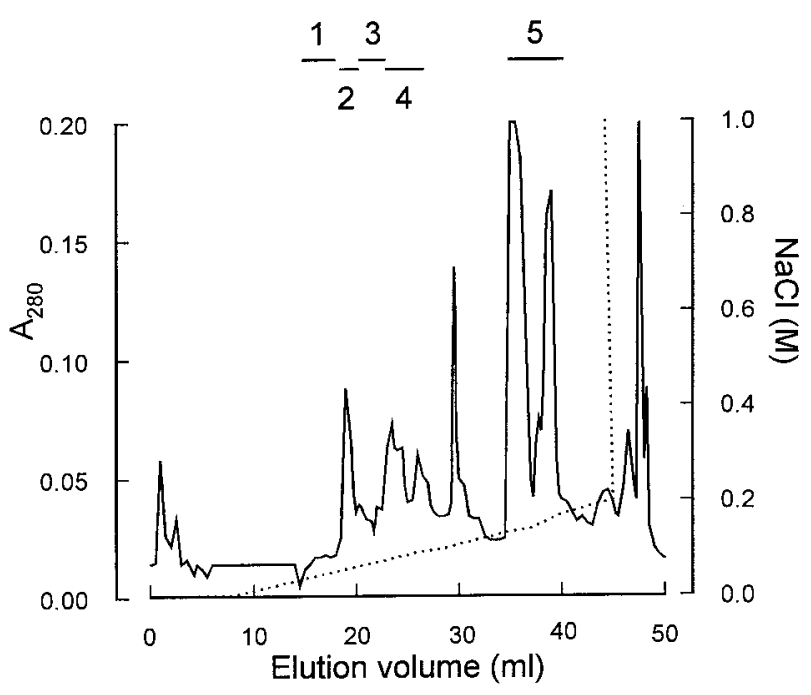

FIGURE 1. Anion exchange chromatography of phase 3 6-30 kDa tammar whey. Fractions described by numbers were tested in lactating mouse mammary acini. Solid line, $\mathrm{A}_{280}$. Dashed line, $\mathrm{NaCl}$ gradient.

Antibody Production Unit, Carluke, UK) and $O$-phenylenediamine in citrate phosphate buffer $\left(0 \cdot 1 \mathrm{M} \mathrm{NaH}{ }_{2} \mathrm{PO}_{4} \cdot 2 \mathrm{H}_{2} \mathrm{O}, 50 \mathrm{mM}\right.$ citric acid, $\left.\mathrm{pH} 5 \cdot 5\right)$ containing $0.012 \% \quad \mathrm{H}_{2} \mathrm{O}_{2}$. The absorbance was measured at $492 \mathrm{~nm}$ using a Labsystems MCC platereader (Helsinki, Finland).

\section{Statistical analysis}

Results are presented as means \pm S.E.M. for $\mathrm{n} \geq 3$. Statistical significance was determined by general linear mean analysis or Student's paired $t$-test.

\section{RESULTS}

Tammar milk fractions were initially screened for an inhibitor of milk secretion in rabbit mammary explants cultures, a system used previously to identify an autocrine regulator of milk secretion in goat's milk (Wilde et al. 1995a). When tested at equal protein concentration, inhibition of lactose synthesis was observed with phase $2 \mathrm{~B}$ but not phase 3 whey (Table 1). Preparation of $6-30 \mathrm{kDa}$ whey fractions, and exclusion of a greater proportion of phase 3 whey proteins, revealed inhibitory activity in both phase $2 \mathrm{~B}$ and phase 3 tammar whey. Fractions containing phase $2 \mathrm{~B}$ and phase 3 whey constituents of $>30 \mathrm{kDa}$ had no effect (Table 1). Based on these initial observations, the $6-30 \mathrm{kDa}$ whey constituents from phase 3 milk were resolved by anion exchange chromatography (Fig. 1), and a 


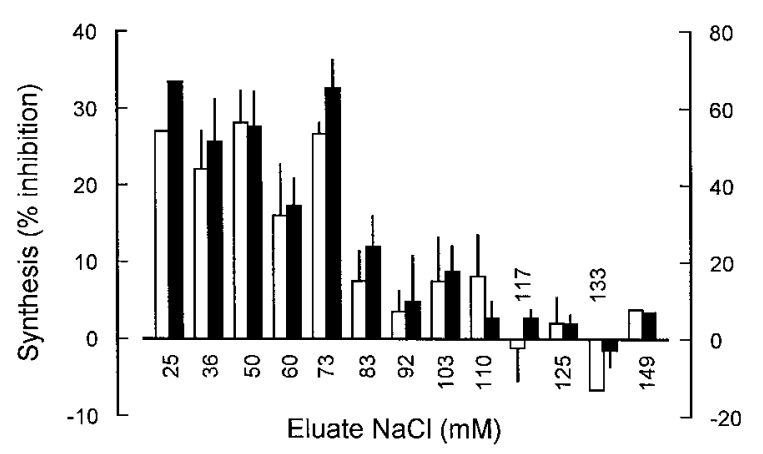

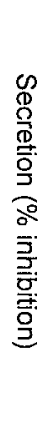

FIGURE 2. Inhibition of protein synthesis and secretion in mouse mammary acini by phase 3 tammar milk fractions. The abscissa shows the upper limiting salt concentration of consecutive fractions eluted by an $\mathrm{NaCl}$ gradient during anion exchange chromatography of 6-30 kDa phase 3 tammar whey proteins. Fractions were tested for their ability to inhibit protein synthesis (open bars) and protein secretion (filled bars). Results are the mean \pm s.E.M. ( $n=3$ animals $)$.

series of fractions covering the entire salt gradient were tested for their ability to inhibit protein secretion in suspension cultures of mouse mammary acini. Bioassay in acini culture measured essentially the same response as tissue explant culture, i.e. the ability of milk fractions to inhibit synthesis and secretion of key milk constituents, and comparison of key milk fractions in each system confirmed that they produced similar effects (results not shown). Bioassay of fractions from three individual animals showed inhibitory activity in acini consistently associated with fractions in the range $0-73 \mathrm{mM}$ salt (Fig. 2). Other fractions constituting the majority of the whey proteins had no significant effect. Similar results were obtained with two samples of phase 3 milk pooled from several animals (results not shown).

SDS-PAGE of the inhibitory fractions of phase 3 whey showed that each contained a mixture of proteins, with several protein bands common to two or more fractions (Fig. 3). To obtain fractions containing discrete populations of proteins, proteins eluting at $0-73 \mathrm{mM}$ salt were collected according to their $\mathrm{A}_{280}$ elution profile. With this strategy, inhibition of protein secretion in acini cultures was associated with fractions designated 1 and 4 (Fig. 4), which eluted at $35-45 \mathrm{mM}$ and $60-73 \mathrm{mM} \mathrm{NaCl}$ respectively (Fig. 1).

The protein composition of inhibitory fractions 1 and 4 was assessed by SDS-PAGE and comparison with the known molecular weights of tammar milk proteins (Nicholas et al. 1997), by immunoblotting and by non-competitive ELISA using specific antibodies. Resolution of fraction 1 by SDS-PAGE

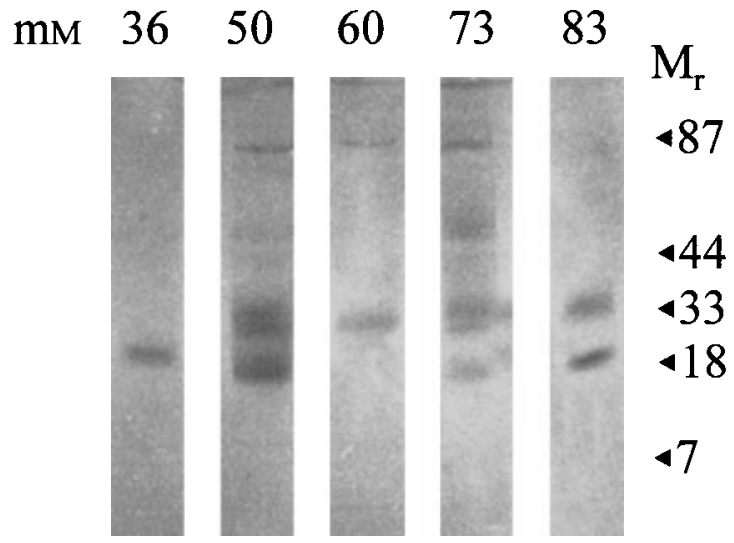

FIGURE 3. SDS-PAGE of phase 3 tammar whey proteins. A $6-30 \mathrm{kDa}$ fraction of tammar whey was subjected to anion exchange chromatography and consecutive fractions eluted by an $\mathrm{NaCl}$ gradient were resolved by SDS-PAGE. For each fraction, $5 \mu \mathrm{g}$ total protein were loaded. Positions of markers of known relative molecular masses (in thousands) are shown.

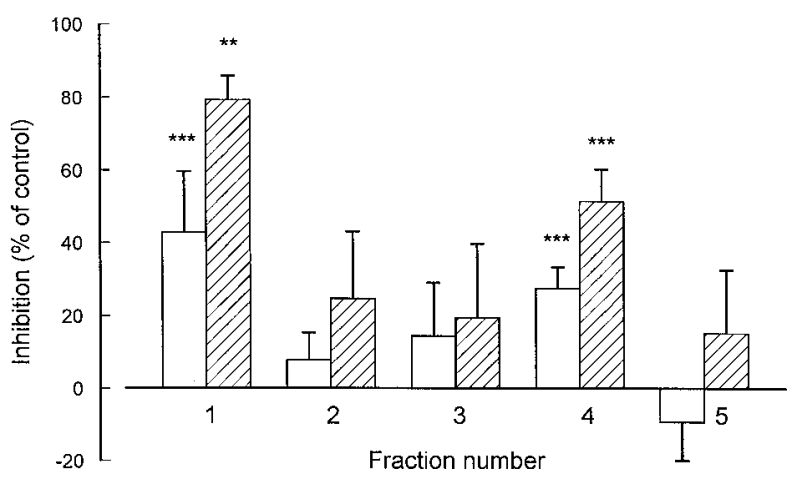

FIGURE 4. Effect of phase 3 proteins on protein synthesis and secretion in mouse mammary acini. The 6-30 kDa phase 3 tammar whey protein fractions were collected according to $\mathrm{A}_{280}$ elution profile during anion exchange chromatography (see Fig. 1). Protein fractions were tested at equal protein concentration for their ability to inhibit protein synthesis (open bars) and secretion (hatched bars). Values are the mean \pm s.E.M. for four or five experiments. ${ }^{*} P<0 \cdot 01$, *** $P<0.001$ compared with untreated controls.

identified prominent bands migrating at 66 and $63 \mathrm{kDa}$ (Fig. 5A), and in non-competitive ELISA the fraction showed weak reactions with antisera against $\beta$-lactoglobulin $(18 \mathrm{kDa})$ and with LLP-A $(24 \mathrm{kDa})$, a major whey protein in phase 3 tammar milk (Nicholas et al. 1987) (Fig. 6). This antiserum probably also recognises the $\mathrm{B}$ isoform of LLP (Nicholas et al. 1987). Fraction 4 showed similar 66 and $63 \mathrm{kDa}$ bands on SDS-PAGE and a strong band of $18 \mathrm{kDa}$ (Fig. 5A) which, based on ELISA 
A

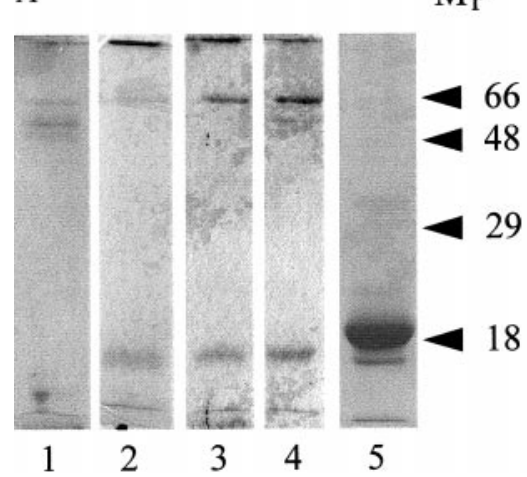

B

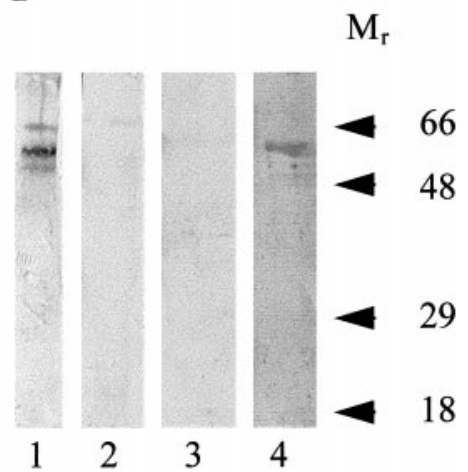

FIGURE 5. SDS-PAGE and immunoblotting of phase 3 tammar whey fractions for bovine FIL. (A) Milk fractions 1-5 representing $A_{280}$ peaks collected during anion exchange chromatography (see Fig. 1) of phase 3 6-30 kDa whey were resolved by SDS-PAGE. (B) Western blotting was performed using a polyclonal antiserum against bovine FIL (Wilde et al. 1995a). Gel tracks were loaded with equal amounts of protein. Positions of markers of known relative molecular masses (in thousands) are shown.

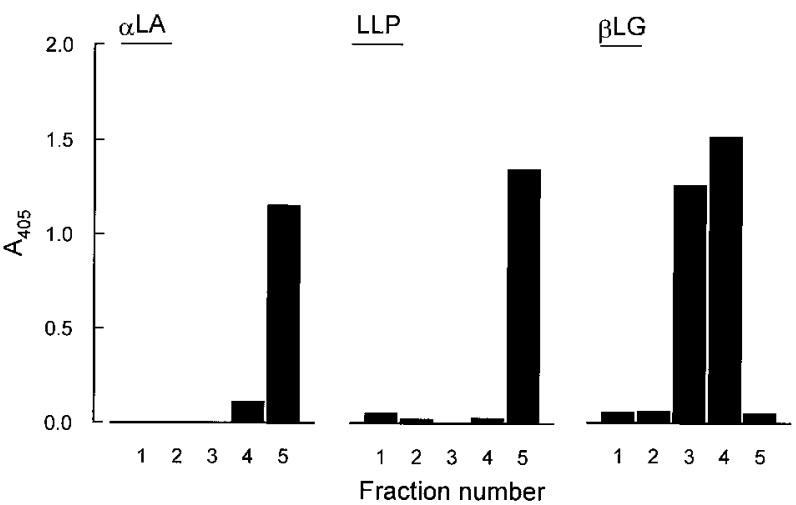

FIGURE 6. Distribution of milk proteins in phase 3 tammar whey fractions. Fractions were obtained by anion exchange chromatography of $6-30 \mathrm{kDa}$ phase 3 tammar whey proteins, and tested in non-competitive ELISA using antisera against tammar $\alpha$-lactalbumin $(\alpha \mathrm{LA})$, tammar LLP-A (LLP) and ovine $\beta$-lactoglobulin $(\beta \mathrm{LG})$. Results are from a representative assay.

data, is likely to be $\beta$-lactoglobulin (Fig. 6). Inhibition of mammary secretion by fractions 1 and 4 is, however, unlikely to be due to LLP or $\beta$-lactoglobulin. LLP-A and LLP-B were found predominantly in fraction 5 (Fig. 6), which was not inhibitory in the bioassay (Fig. 4). Likewise, the $\beta$-lactoglobulin content of fraction 3 was similar to that of fraction 4 and in excess of that in fraction 1 (Fig. 6), but fraction 3 did not inhibit protein secretion in mammary acini cultures (Fig. 4). On the other hand, the $63 \mathrm{kDa}$ band common to fractions 1 and 4 was recognised in Western blotting by a polyclonal antiserum raised against a bovine FIL (Wilde et al. 1995a) (Fig. 5B). Anti-FIL antiserum showed negligible reaction with fractions 2 and 3, which were inactive in cell culture bioassay (Fig. 4). The presence of high molecular weight bands in fractions 1 and 4 was unexpected, since the material was derived from ultrafiltered whey, and contrasted with the fractions' elution profiles during gel filtration chromatography. Gel filtration of inhibitory fractions 1 and 4 confirmed the absence of molecules $>30 \mathrm{kDa}$, and showed only one protein of $5.7 \mathrm{kDa}$ common to the two fractions (results not shown).

Phase 3 and phase 2B tammar milk differ in protein composition (Nicholas et al. 1997) but, as with phase 3 milk, whole whey from phase $2 \mathrm{~B}$ milk and a $6-30 \mathrm{kDa}$ fraction thereof inhibited casein and lactose synthesis in rabbit explant cultures (Table $1)$. The small volumes of milk obtainable at this stage of lactation $(\sim 0.5 \mathrm{ml}$ per animal) and the low protein content of phase $2 \mathrm{~B}$ whey, reflected in the anion exchange elution profile of the $6-30 \mathrm{kDa}$ fraction (Fig. 7A), precluded extensive bioassay of anion exchange fractions. However, using pooled material from ten animals, acinar protein synthesis and secretion were inhibited by an anion exchange fraction eluting at $35-80 \mathrm{mM} \mathrm{NaCl}$, similar to the elution position of phase 3 fractions 1 and 4 (Fig. 7B). Western blotting of phase 2B whey fractions with anti-FIL antiserum also indicated the presence of an inhibitory protein in phase $2 \mathrm{~B}$ milk. SDS-PAGE showed the presence of a $66 \mathrm{kDa}$ component in protein eluting at $55-80 \mathrm{mM} \mathrm{NaCl}$ during anion exchange chromatography, and 

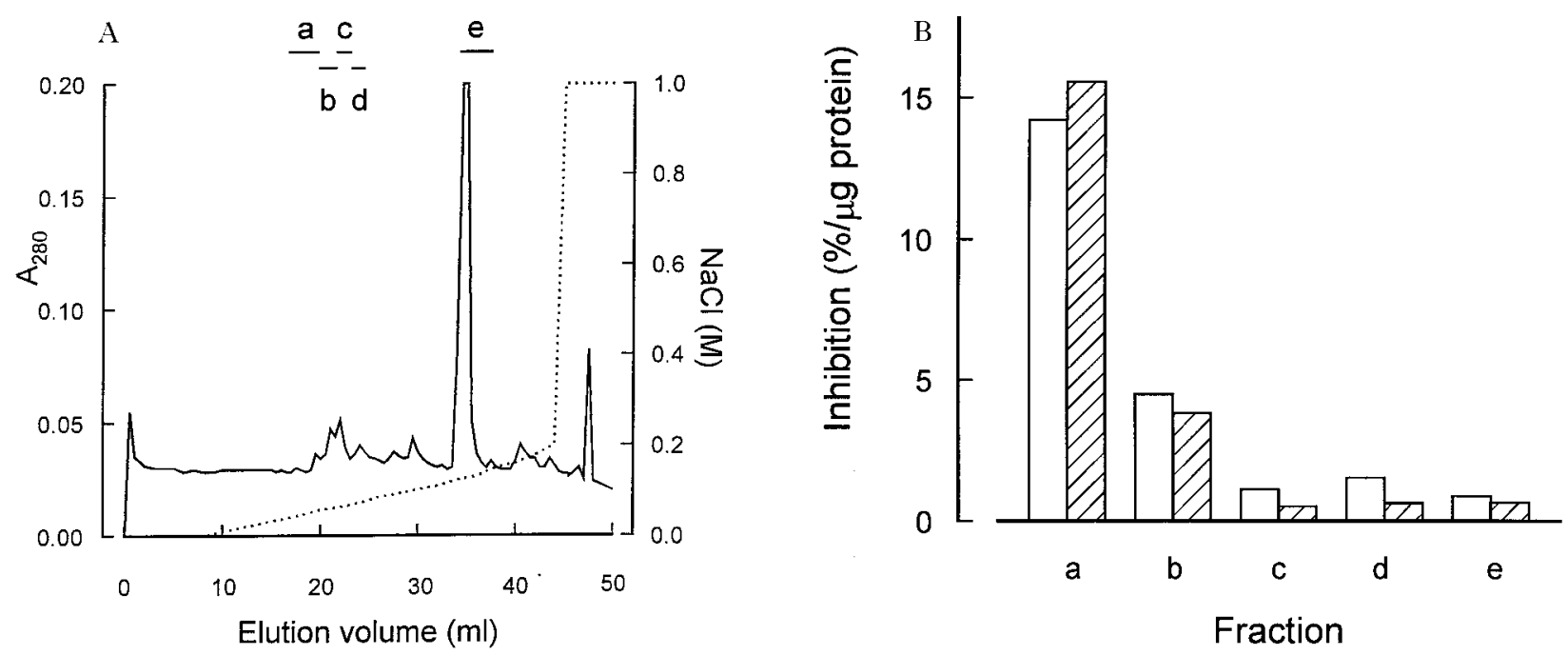

FIGURE 7. Anion exchange chromatography and bioassay of phase $2 \mathrm{~B}$ 6-30 kDa tammar whey. (A) Whey fraction from pooled phase $2 \mathrm{~B}$ milk was subjected to anion exchange chromatography and fractions a-e were collected according to $\mathrm{A}_{280}$ elution profile. (B) Fractions a-e were assayed for inhibition of protein synthesis (open bars) and protein secretion (hatched bars). Inhibition on a unit protein basis is expressed as a percentage of untreated controls. Values are the mean of duplicate determinations.

A

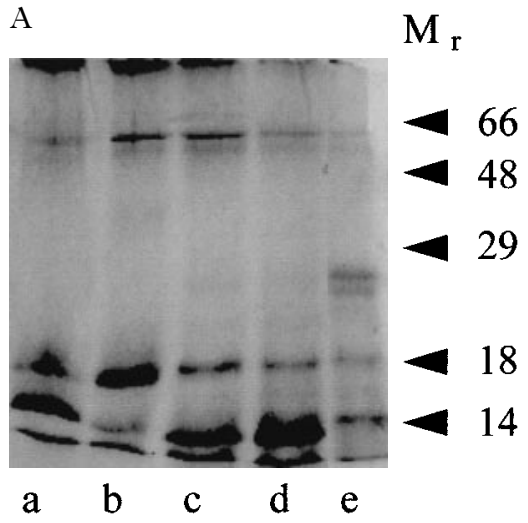

B

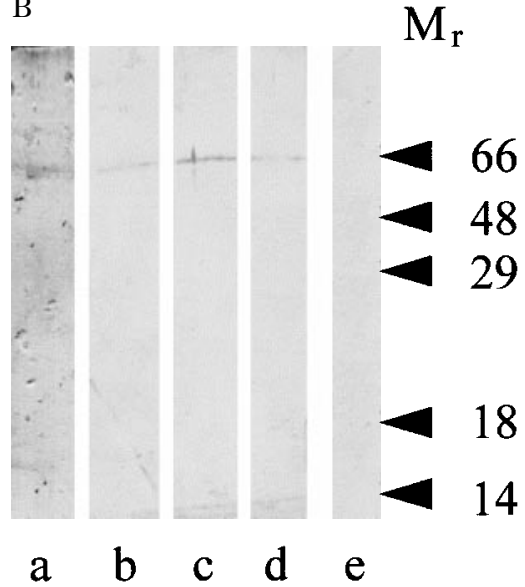

FIGURE 8. SDS-PAGE and immunoblotting of phase $2 \mathrm{~B}$ tammar whey fractions for bovine FIL. Phase $2 \mathrm{~B}$ whey fractions a-e obtained by anion exchange chromatography (see Fig. 7A) were resolved by SDS-PAGE and (A) stained with Coomassie Blue or (B) subjected to Western blotting using antiserum specific for bovine FIL. Tracks were loaded on an equal protein basis. Positions of markers of known relative molecular masses (in thousands) are shown.

principally in fraction $\mathrm{c}$ at $65-70 \mathrm{mM}$ (Fig. 8A). This band was recognised specifically by anti-FIL antiserum (Fig. 8B). The presence of LLP-A in fraction $\mathrm{c}$, and also in the principal phase $2 \mathrm{~B}$ peak, designated $\mathrm{e}$, was shown by non-competitive ELISA, and reflects the late stage of phase $2 \mathrm{~B}$ lactation necessary to obtain sufficient milk for analysis (results not shown).

\section{DISCUSSION}

The change in suckling pattern during the transition from phase $2 \mathrm{~B}$ to phase 3 of lactation (TyndaleBiscoe \& Janssens 1988) suggests that, as in other species, milk secretion rate in the tammar wallaby may be dependent on frequency and completeness of milk removal. In this study, tissue and cell 
culture bioassay showed that phase 3 tammar milk contains proteins able to inhibit the secretion of milk constituents. Both proteins cross-reacted with antisera raised against a bovine autocrine inhibitor of lactation (Addey et al. 1995, Wilde et al. 1995a), suggesting that they may perform a similar function in the tammar, i.e. marsupial milk secretion may be under autocrine control through feedback inhibition by a milk constituent, as it is in dairy animals (Wilde et al. 1995a,b). The structure of the inhibitory proteins in tammar milk has yet to be determined. However, it was notable that they, like the FIL proteins isolated from goat's and cow's milk, behaved anomalously in SDS-PAGE. Although previously ultrafiltered through a $30 \mathrm{kDa}$ cut-off membrane, the FIL-related proteins in tammar milk migrated in SDS-PAGE with apparent molecular masses of 66 and $63 \mathrm{kDa}$. The caprine FIL also migrates at $\sim 66 \mathrm{kDa}$ in SDS-PAGE, but passes through the $30 \mathrm{kDa}$ ultrafiltration membrane, and elutes on gel filtration with a molecular mass of $7 \cdot 4 \mathrm{kDa}$ (Wilde et al. 1995a). Similarly, gel filtration of inhibitory fractions 1 and 4 has confirmed the absence of molecules of $>30 \mathrm{kDa}$ and shown only one protein of $5 \cdot 7 \mathrm{kDa}$ common to the two fractions (results not shown). Thus, the presence of high molecular weight bands in ultrafiltered tammar phase 3 whey may be explained by the characteristically anomalous behaviour of molecules which share an ability to inhibit secretion in mammary culture bioassays.

The inhibitory proteins in phase 3 tammar milk may provide a mechanism for matching the mother's milk supply with the changing demand of the developing young as its growth accelerates, and its diet becomes increasingly more herbivorous (Tyndale-Biscoe \& Janssens 1988). That is, feedback inhibition may act to regulate milk secretion rate according to frequency or completeness of milk removal from the mammary gland (Peaker \& Wilde 1996). Control of milk secretion rate may be signalled by changes in FIL's concentration in milk. Thus, addition of purified caprine FIL to milk stored in one goat mammary gland decreased milk secretion rate temporarily, and in a concentrationdependent manner (Wilde et al. 1995a). Conversely, immunological neutralisation of FIL in goat's milk elicited a temporary increase in milk secretion rate (Wilde et al. 1996). Alternatively, or in addition, autocrine feedback may be modulated by changing the activity of a receptor-mediated signal transduction pathway (Wilde et al. 1997a). Whichever is the case, the intracellular effect of autocrine feedback is to block constitutive secretion in the mammary epithelial cells (Rennison et al. 1993). The inhibitory activity of phase 2B tammar milk fractions in tissue and cell culture bioassays suggests that feedback inhibition may also control milk secretion during the period when the young is intermittently attached to the teat. Inhibition was, as in phase 3 , associated with $6-30 \mathrm{kDa}$ whey proteins, and Western blotting showed that the activity was ascribable to the presence of a FIL-like protein in milk. Tammar milk proteins, like milk composition itself, are regulated asynchronously throughout lactation. The expression and concentration of some milk proteins change significantly, whereas others are expressed at relatively constant levels (Messer \& Elliot 1987, Bird et al. 1994, Nicholas et al. 1994, 1995, 1997). If the expression or milk concentration of tammar FIL is amongst those which changes during the transition to phase 3 , it could be an important determinant of the increase in milk secretion and, by analogy with other species (Peaker \& Wilde 1996, Wilde et al. 1997b), the developmental adaptations which act to sustain it. Bioassay suggested that, when compared at equal concentrations, the whey protein fraction of phase $2 \mathrm{~B}$ milk was indeed more inhibitory than that derived from phase 3 milk. On this basis, and taking into account the concentration of whey proteins in phase $2 \mathrm{~B}$ and phase 3 milk $(15 \cdot 7$ and $30.9 \mathrm{mg} / \mathrm{ml}$ respectively), inhibition compared on a milk volume basis is calculated to be $>10$-fold higher in phase $2 \mathrm{~B}$ milk. Thus, the transition to phase 3 of lactation may be promoted by a decrease in FIL-mediated autocrine feedback on milk secretion.

\section{REFERENCES}

Addey CVP, Peaker M \& Wilde CJ 1995 Control of milk secretion. US Patent SN 08/395,535.

Bird PH, Hendry KAK, Shaw D, Wilde CJ \& Nicholas KR 1994 Progressive changes in milk protein gene expression and prolactin binding during lactation in the tammar wallaby (Macropus eugenii). Fournal of Molecular Endocrinology $\mathbf{1 3}$ $117-125$.

Daly SEJ, Owens RA \& Hartmann PE 1993 The short term synthesis and infant regulated removal of milk in lactating women. Experimental Physiology 78 209-220.

Dove H \& Cork S 1989 Lactation in the tammar wallaby (Macropus eugenii). I. Milk consumption and the algebraic description of the lactation curve. Fournal of Zoology 219 385-397.

Green B 1984 Composition of milk and energetics of growth in marsupials. In Physiological Strategies in Lactation; Symposia of the Zoological Society of London, vol 51, pp 360-387. Eds M Peaker, RG Vernon \& CH Knight. London: Academic Press.

Green B \& Merchant J 1988 The composition of marsupial milk. In The Developing Marsupial: Models for Biomedical Research, pp 68-75. Eds CH Tyndale-Biscoe \& PA Janssens. Heidelberg: Springer-Verlag.

Kuhn NJ \& White A 1975 The topography of lactose synthesis. Biochemical Fournal 148 77-84. 
Labarca C \& Paigen K 1980 A simple, rapid and sensitive DNA assay procedure. Analytical Biochemistry 102 344-352.

Laemmli UK 1970 Cleavage of structural proteins during the assembly of the head of bacteriophage T4. Nature 227 680-685.

Maher F \& Nicholas KR 1987 Pituitary-induced lactation in mammary gland explants from the pregnant tammar (Macropus eugenii): a negative role for cyclic AMP. Comparative Biochemistry and Physiology 87 1107-1117.

Messer M \& Elliot C 1987 Changes in $\alpha$-lactalbumin, total lactose, UDP-galactose hydrolase and other factors in tammar wallaby (Macropus eugenii) milk during lactation. Australian Fournal of Biological Sciences $\mathbf{4 0}$ $37-46$.

Nicholas KR $1988 a$ Control of milk protein synthesis in the tammar wallaby: a model system to study prolactindependent development. In The Developing Marsupial: Models for Biomedical Research, pp 68-85. Eds CH Tyndale-Biscoe \& PA Janssens. Heidelberg: SpringerVerlag.

Nicholas KR $1988 b$ Asynchronous dual lactation in a marsupial, the tammar wallaby (Macropus eugenii). Biochemical and Biophysical Research Communications 134 529-536.

Nicholas KR, Messer M, Elliot C, Maher F \& Shaw DC 1987 A novel protein synthesised only in late lactation by the mammary gland of the tammar wallaby (Macropus eugenii). Biochemical Fournal 241 891-904.

Nicholas KR, Wilde CJ, Bird PH \& Hendry KAK 1994 Asynchronous expression of milk protein genes during lactation in the tammar wallaby (Macropus eugenii). Trends in Comparative Biochemistry and Physiology Research 1 959-972.

Nicholas KR, Wilde CJ, Bird PH, Hendry KAK, Tregenza K \& Warner B 1995 Asynchronous concurrent secretion of milk proteins in the tammar wallaby (Macropus eugenii). In Intercellular Signalling in the Mammary Gland, pp 153-170. Eds CJ Wilde, M Peaker \& CH Knight. New York: Plenum Press.

Nicholas K, Simpson K, Wilson M, Trott J \& Shaw D 1997 The tammar wallaby: a model to study putative autocrineinduced changes in milk composition. Fournal of Mammary Gland Biology and Neoplasia 2 299-310.

Osborne R, Howell M, Clark AJ \& Nicholas KR 1995 Hormone-dependent expression of the ovine $\beta$-lactoglobulin gene. Fournal of Dairy Research 62 321-329.

Peaker M 1995 Autocrine control of milk secretion: development of the concept. In Intercellular Signalling in the Mammary Gland, pp 193-202. Eds CJ Wilde, M Peaker \& $\mathrm{CH}$ Knight. New York: Plenum Press.
Peaker M \& Wilde CJ 1996 Feedback control of milk secretion from milk. Fournal of Mammary Gland Biology and Neoplasia $1307-315$.

Poole WE, Simms NG, Wood JT \& Lubulwa M 1991 Tables for age determination of the Kangaroo Island wallaby (tammar), Macropus eugenii, from body measurements. Technical Memorandum 32. Lyneham, Australia: CSIRO Division of Wildlife and Ecology.

Prentice A, Addey CVP \& Wilde CJ 1989 Evidence for local feedback control of human milk secretion. Biochemical Society Transactions 1522.

Rennison ME, Kerr M, Addey CVP, Handel SE, Turner MD, Wilde CJ \& Burgoyne RD 1993 Inhibition of constitutive protein secretion from lactating mouse mammary epithelial cells by FIL (feedback inhibitor of lactation), a secreted milk protein. Fournal of Cell Science 106 641-648.

Towbin H, Staehelm T \& Gordon J 1979 Electrophoretic transfer of proteins from polyacrylamide gels to nitrocellulose sheets: procedure and some applications. Proceedings of the National Academy of Sciences of the USA $764350-4356$.

Tyndale-Biscoe CH \& Janssens PA 1988 The Developing Marsupial: Models for Biomedical Research. Heidelberg: Springer-Verlag.

Wilde CJ, Razooki Hasan H \& Mayer RJ 1984 Comparison of collagen gels and mammary extracellular matrix as substrates for study of terminal differentiation in mammary epithelial cells. Experimental Cell Research 151 519-532.

Wilde CJ, Addey CVP, Boddy LM \& Peaker M $1995 a$ Autocrine regulation of milk secretion by a protein in milk. Biochemical fournal 305 51-58.

Wilde CJ, Addey CVP, Boddy-Finch LM \& Peaker M $1995 b$ Autocrine control of milk secretion: from concept to application. In Intercellular Signalling in the Mammary Gland, pp 227-237. Eds CJ Wilde, M Peaker \& CH Knight. New York: Plenum Press.

Wilde CJ, Addey CVP \& Peaker M 1996 Effect of immunisation against an autocrine inhibitor of milk secretion. Fournal of Physiology 491 465-469.

Wilde CJ, Addey CVP, Bryson JM, Finch LMB, Knight CH \& Peaker M. $1997 a$ Autocrine regulation of milk secretion. In Mammary Development and Cancer; Biochemical Society Symposia, vol 63, pp 81-89. Eds DG Fernig, PS Rudland, S Leinster \& GG Lunt. London: Portland Press.

Wilde CJ, Quarrie LH, Tonner E \& Flint DJ $1997 b$ Mammary apoptosis: physiological regulation and molecular determinants. In Biological Signalling and the Mammary Gland, pp 103-113. Eds CJ Wilde, M Peaker \& E Taylor. Ayr: Hannah Research Institute.

REVISED MANUSCRIPT RECEIVED 23 April 1998 